\title{
TAJEMNICA WCIELENIA W NAUCZANIU LEONA WIELKIEGO
}

Ramy niniejszego wystąpienia o tematyce tajemnicy wcielenia w nauczaniu św. Leona Wielkiego zmuszają do wyboru pewnej węższej kwestii z tej bardzo szerokiej dziedziny, która przecież należała do koronnych tematów, absorbujących wszystkich ówczesnych teologów Kościoła. Nasz autor patrzy na kwestie chrystologiczne przede wszystkim przez pryzmat soteriologii. Wcielenie i odkupienie stoją w najściślejszej zależności: odkupienie jest postulatem wcielenia. Właśnie ten element i zakorzenienie w tradycji depozytu wiary apostolskiej pozwala mu na stałą weryfikację poszukiwań teologa w duchu odpowiedzialności za przepowiadanie o tajemnicy zbawienia przez Chrystusa i w Chrystusie. To m.in. sprawia, że jego nauczanie jest tak wyważone, a jednocześnie pozostaje otwarte na poszukiwania dwóch ówczesnych głównych kierunków teologii, jakie reprezentują linia aleksandryjska i antiocheńska ${ }^{1}$.

Soteriologiczne implikacje wcielenia rozciągają się szeroko na wszystkie wymiary rzeczywistości ziemskiej, do tego stopnia, że można w przypadku nauczania św. Leona Wielkiego mówić o wcieleniu jako o głównej osi historiozofii. Tematyka ta dojrzewała zwłaszcza pod wpływem bolesnego doświadczenia załamania się i rozpadu wielowiekowego modelu cywilizacji rzymskiej zachodniej ${ }^{2}$. Niniejsze wystąpienie będzie chciało pokrótce przybliżć jedynie sposób ukazywania przez Leona Tajemnicy Słowa Wcielonego w kontekście swoich czasów. Jest to nauczanie biskupa Rzymu, który ma żywą świadomość swej misji czuwania nad apostolskim depozytem wiary i strzeżenia jedności. Bazą jego nauczania doktrynalnego jest tradycja egzegezy i credo apostolskie.

\footnotetext{
${ }^{1}$ Chrystologia Leona Wielkiego w kontekście soteriologii, zob. zwlaszcza: W. Wojtasik, Nauka św. Leona I papieża o Stowie Wcielonym, Warszawa 1936, 84-126; B. Studer, Soteriologie in der Schrift und Patristik, HDG III 2a, Freiburg 1978, 200-212.

${ }^{2}$ Por. Cz. Bartnik, Wcielenie jako podstawa teologii historii u Leona Wielkiego, RTK 7 (1960) z. 4, 21-51; tenże, Teologia historii wedtug Leona Wielkiego, Lublin 1972.
} 
1. Postać św. Leona na tle swoich czasów. Św. Leon jawi się jako niezwykła osobowość, gdy chodzi o formację teologiczną, kulturową i szerokie horyzonty intelektualne. Do tego dołączył się charyzmat pasterza, bez reszty oddanego posługiwaniu Kościołowi, utwierdzaniu chrześcijańskiego nauczania a jednocześnie uczestniczenia w wielkim stylu w tworzeniu nowej cywilizacji Europy. Historia nadała mu zaszczytny tytuł „Wielkiego” Doktora. Leon tkwił głęboko w kręgu najważniejszych spraw ówczesnego Kościoła. W r. 418 jako akolita woził do Kartaginy listy od papieża Zozyma w sprawie sporów pelagiańskich. Za pontyfikatu Celestyna był diakonem, biorącym żywy udział w corocznych synodach rzymskich oraz w kontaktach Stolicy Apostolskiej z dworem cesarskim w Rawennie, zwłaszcza z wielką chrześcijanką Gallą Placydią, matką cesarza Walentyniana III. W r. 429 jako archidiakon zwracał się do Jana Kasjana z prośbą o ocenę poglądów Nestoriusza i służenie teologiczną radą w tym względzie papieżowi. Pod koniec pontyfikatu Sykstusa III, w sierpniu 440 r., sam dwór cesarski powierzył mu delikatną misję zażegnania groźnego dla całego imperium sporu pomiędzy Aecjuszem, wszechwładnym wodzem armii, a ambitnym namiestnikiem Galii Albinusem. Mimo nieobecności w Rzymie został wybrany papieżem i 29 października tegoż roku wyświęcony na biskupa. Odtąd datuje się szczyt jego działalności i znaczenia.

Przy ocenie działalności papieża Leona (440-461) nieodzowną jest rzeczą mieć na uwadze szerszy kontekst historyczny. Jest to przede wszystkim czas dramatycznego schyłku zachodniego cesarstwa rzymskiego. Na Wieczne Miasto napadają kolejno: Alaryk, król Wizygotów w 410 r., Attyla, wódz Hunnów w 452 r. i Genzeryk, król Wandalów w 455 r. Instytucje państwa rzymskiego są w stanie agonii: rozpadły się struktury legionów, a razem $\mathrm{z}$ nimi administracja państwowa i władza cesarska; wciąż narastały przy tym tarcia i walki wewnętrzne w całym imperium. Był to przy tym okres nasilonej wędrówki ludów: $\mathrm{z}$ północno-wschodnich rejonów kontynentu przesuwały się na tereny zachodniego Imperium wraz $\mathrm{z}$ armiami plemion gockich całe populacje. Zaznaczał się ogólny upadek gospodarczy, handlowy, kulturalny i naukowy. Wzrastał ucisk społeczny w miastach, a zwłaszcza w rolnictwie. Urzędnicy uciekali masowo $\mathrm{z}$ miast na wieś lub wstępowali do wspólnot klasztornych. W powszechnym rozprzężeniu i upadku poganie widzieli karę bogów rzymskich za odstępstwo od religii ojców. Chrześcijanie natomiast, którzy interpretowali czasy w świetle chrystologii, dopatrywali się w ówczesnych trudach i nieszczęściach pasyjnego przygotowania Kościoła do wielkiego triumfu. Ratunku szukali więc w religii chrześcijańskiej, którą wraz z Leonem uważali za jedyną ostoję społeczności, najwyższą zasadę życia ludzkiego i duszę Imperium. Żeby jednak tak było w rzeczywistości, papieże starali się przede wszystkim odbudować moralność chrześcijańską oraz instytucje Kościoła: tradycję, dyscyplinę, prawodawstwo, sprawną administrację, teologię, budownic- 
two sakralne, a przede wszystkim wybieranie wybitnych osobowości na biskupów w terenie ${ }^{3}$.

2. Wobec dwóch tradycji chrystologicznych. W pierwszej połowie $\mathrm{V}$ wieku, tj. za czasów Leona, istniały uformowane dwie tradycje teologiczne w podejściu do kwestii chrystologicznych : antiocheńska i aleksandryjska. Pierwsza, zarysowana w nauczaniu Diodora z Tarsu i jego ucznia Teodora z Mopswestii, wyrosła w klimacie polemiki z Eunomiuszem i apollinarystami. Do zasadniczych jej tematów należały: Deus assumens i homo assumptus. Podkreślając pełne człowieczeństwo Jezusa, linia ta miała na uwadze również jedność w Chrystusie: tajemnica zjednoczenia dwóch natur wyrażana jest przez jedno prosopon, z tym że prosopon jawi się jako rezultat zjednoczenia, a nie jako punkt wyjścia. Przy opisie tej jedności odwołuje się raczej do kategorii moralnych, jak synapheia, tj. jedność miłości. W tradycji teologicznej zwykło się tu w pewnym uproszczeniu mówić o schemacie Logos - anthropos. Jego najbardziej skrajną formę można dostrzec w nauczaniu Nestoriusza, bpa Konstantynopola, potępionego i złożonego z urzędu w 431 r. na soborze w Efezie.

Tradycja zaś aleksandryjska, sięgająca czasu jeszcze przednicejskiego, bardziej akcentowała zjednoczenie natur, mając na uwadze ideę, formułowaną przez naukę Atanazego, że ,co nie zostało przyjęte, nie może być odkupione". W V w. ten kierunek, ujmowany schematycznie jako Logos - sarks, będzie ilustrowała obiegowa formuła Cyryla Aleksandryjskiego, przyjęta faktycznie z nauczania Atanazego: „Logos nie wstąpił w człowieka, ale stał się człowiekiem pozostając Bogiem"4 . Krańcową formą i zniekształceniem tej linii będzie monofizytyzm Eutychesa ${ }^{5}$.

Nieporozumienia odnośnie do terminologii - dotyczyło to kluczowych terminów, takich jak physis, hypostasis, prosopon - połączone $\mathrm{z}$ animozjami politycznymi i ambicjami, przynosiły owoc w postaci nowego zaognienia sporów, czego ilustracją może być synod z 449 r. w Efezie, określany jako zbójecki ${ }^{6}$. Podejście do problematyki chrystologicznej pośród teologów Zachodu w V w. jest odmienne. ,Szkoła rzymska za Leona - jak słusznie zauważył Cz. Bartnik - oceniała wartość chrystologii przede wszystkim przez pryzmat siły wiązania Chrystusa z całą doczesną egzystencją człowieka i społeczeństw. Głównym probierzem jakiejś nauki była realność, prawdziwość, faktyczność i głębia życiodajna związania Boga z człowiekiem. Z tego punktu widzenia papieże gwałtownie odrzucali wszystkie błędy chrystologiczne: gnostycyzm, 440-451.

${ }^{3}$ Por. Cz. Bartnik, Ku integralnej chrystologii - Leon Wielki, AK 71 (1979) t. 92, z. 422,

4 Por. Cyrillus Alexandrinus, De sancta et consubstantiali Trinitate dial. 1; Athanasius Alexandrinus, Oratio contra arianos III 30.

5 Por. B. Studer, Dio Salvatore nei Padri della Chiesa, Roma 1986, 282-286.

6 Por. H. Pietras, Poczq̨tki teologii Kościoła, Kraków 2000, 219-224. 
manicheizm, arianizm, adopcjanizm, pryscylianizm, apolinaryzm, pelagianizm, i - ostatnio - nestorianizm oraz monofizytyzm. Weźmy ważniejsze przykłady. W arianizmie nie ma rzeczywistego związania Boga z człowiekiem, bo Chrystus nie jest uważany za Boga. Według pelagianizmu Bóg nie wkracza w dzieje ludzkie ontycznie, a tylko przez moralny przykład Chrystusa. Rzym zrozumiał nestorianizm jako naukę o «dwóch Chrystusach»: prawdziwie historycznym Jezusie, i niebiańskim Logosie, Słowie, przy czym nie ma realnego spotkania między Bogiem a człowiekiem, nawet w Jezusie Chrystusie, człowieczeństwo i bóstwo spotykają się w nim tylko najwyżej przez miłość. Monofizytyzm, w rozumieniu Leona, uczy, że w Chrystusie Bóg złączył się z człowiekiem tylko przez nieuchwytny moment początkowy, a potem człowieczeństwo zostało przez Słowo wchłonięte, ubezwłasnowolnione, a nawet unicestwione. Stąd w Chrystusie pozostała faktycznie tylko natura Boża, czyli Chrystus jest właściwie samym Bogiem i nie wiąże się z człowiekiem, nie wkracza też w dzieje całej ludzkości, a więc świat doczesny i ludzkość są całkowicie świeckie, bez ontycznego związku z Bogiem"”.

3. Nauka Leona o wcieleniu. Chrystologia Leona dochodzi do głosu niemal we wszystkich jego mowach i listach, chociaż najpełniej zebrana jest w tzw. I Tomie do Flawiana, czyli 28 jego liście ${ }^{8}$, oraz w powtarzającym go w dużej mierze w 165 liście do cesarza Leona z 458 r., zwanym II Tomem Leona ${ }^{9}$. Jest ona dosyć prosta, jasna i raczej niezmienna. Były tego trzy przyczyny: długa tradycja wypracowanej chrystologii ośrodka papieskiego, stosowanie reguły syntezy i integracji nurtów fragmentarycznych oraz posługiwania się językiem literacko-prawniczym. Dla ilustracji zasadniczej stałości tej nauki u niego możemy przytoczyć fragmenty mowy na Boże Narodzenie z r. 440, tj. zaraz na początku działalności jako biskupa Rzymu. Ten fakt przypomina, że Leon posiadał już uformowaną wcześniej, precyzyjną terminologię chrystologiczną, przejętą z nauczania św. Augustyna ${ }^{10}$, którą tylko nieznacznie będzie uzupełniał, zwł. w Tomie do Flawiana. Spójrzmy przeto na ten zasadniczy tekst Leona:

„Słowo Boże, Bóg, Syn Boży, który na początku był u Boga, przez którego: wszystko się stało i bez którego nic się nie stało, stał się człowiekiem dla wybawienia człowieka od śmierci wiecznej. Uniżył się dla przyjęcia naszej małości bez umniejszenia swego majestatu. Pozostając tym, czym był i przyjmując to, czym nie był, zjednoczył prawdziwą postać sługi z tą postacią, w której jest równy Bogu Ojcu. Jedną i drugą naturę zespolił takim związaniem, że niższego nie pochłonęła gloryfikacja, ani wyższego nie pomniejszyło przyjęcie. Niskość więc jest przyjmo-

${ }^{7}$ Cz. Bartnik, Ku integralnej chrystologii, dz. cyt. s. 441.

${ }^{8}$ Por. Epistula 28 = Tomus ad Flavianum, PL 54, 755-782, thum. K. Tomczak, POK 24, ss. XXXVIII-XLIX, lub fragmenty: Breviarium fidei, VI 7, Poznań 1989, 222-226.

${ }^{9}$ Por. Epistula 165, PL 54, 1155-1190.

${ }^{10}$ Por. B. Studer, Il concetto consostanziale in Leone Magno, „Augustinianum” 13 (1973) 599. 
wana przez majestat, słabość przez moc, śmiertelność przez wieczność, z zachowaniem własności jednej i drugiej natury i przy złączeniu się ich w jedną osobę. Dla spłacenia długu naszego położenia natura $z$ istoty swej nie podlegająca cierpieniom scaliła się z naturą podlegającą cierpieniu. W ten sposób Bóg prawdziwy i czlowiek prawdziwy składają się na jedność Pana. A zatem odpowiednio do naszej potrzeby jeden i ten sam pośrednik między ludźmi a Bogiem mógł umrzeć jako jeden oraz zmartwychwstać jako drugi [...]. Gdyby nie był prawdziwym Bogiem, nie przyniósłby odkupienia. Gdyby nie był prawdziwym człowiekiem, nie dałby nam wzoru postępowania" $"$.

„Trzeba zauważyć, pisze dalej ks. Bartnik, że chrystologia papieska bliższa była antiocheńskiej niż aleksandryjskiej w tym czasie. Nic dziwnego, że żyjący na wygnaniu Nestoriusz, zapoznawszy się z nauką Leona zawartą $w$ Tomie, radował się, że doczekał się rehabilitacji i że jego nauka zwyciężyła ${ }^{12}$. Ale faktycznie nauka Leona miała ciągle charakter integracji. Takie bardziej wypośrodkowane stanowisko posiada ona w słynnym Tomie I z 449 roku.

Leon stawia na pierwszym miejscu argumenty biblijne, dopiero potem Skład Apostolski, o którym zresztą sądził, że został ułożony przez Apostołów. Nie wiedział przy tym, że Wschód go nie znał. W kontrowersji z monofizytyzmem uznał za decydujące następujące zdania: «Wierzę w Boga Ojca wszechmogącego i w Jezusa Chrystusa, Syna jego jedynego, Pana naszego, który się narodził z Ducha Świętego i Maryi Panny» ${ }^{13}$. Przeciwko Eutychesowi podkreślał przede wszystkim, oparty na tekstach biblijnych, fakt naradzenia Chrystusa jako człowieka: «dzięki narodzeniu z Maryi [...] prawdziwe ciało wzięte zostało $\mathrm{z}$ ciała» ${ }^{14}$; "z matki Pana wzięta została natura» ${ }^{15}$. Tego historycznego narodzenia się jako człowieka nie należy mylić $z$ odwiecznym narodzeniem Syna w łonie Ojca".

Cała integracyjna chrystologia ośrodka papieskiego oparta jest na schemacie o trzech elementach: natura Boska, natura ludzka i jedność osoby: «Zachowując własność jednej i drugiej natury i wiążąc je w jedną osobę» ${ }^{16}$, «Ten sam i prawdziwym jest Bogiem i prawdziwym człowiekiem [...]. Jeden bowiem i ten sam jest prawdziwym Synem Bożym i prawdziwym Synem człowieczym [...]. W Panu Jezusie Chrystusie, i Bogu i człowieku, zarazem osoba jest jedna» ${ }^{17}$. Dla Leona "ciało» (aspekt aleksandryjski) utożsamia się z realnym, pełnym i nienaruszonym «człowiekiem» (aspekt antiocheński). Pojęcie osoby

${ }^{11}$ Sermo 21,2, CCL 138, 86-88; thum. Cz. Bartnik, Ku integralnej chrystologii, art. cyt., s. 446.

12 Opinia wyrażona w ostatnim, tuż przed śmiercią napisanym dziele Nestoriusza, w Liber Heraclidis, por. H. Pietras, Poczatki teologii, dz. cyt. s. 222.

${ }^{13}$ I. Tomus ad Flavianum 2, PL 54, 757B, thum. Tomczak, POK 24, s. XXXIX.

14 Tamże, 2, PL 54, 763A, POK 24, s. XLI.

15 Tamże, 4, PL 54, 767A, POK 24, s. XLIII.

16 Tamże, 3, PL 54, 763A, POK 24, s. XLI.

17 Tamże, 4, PL 54, 767, POK 24, s. XLIII. 
(persona tłumaczone na greckie: prosopon, nie hypostatis), przejmuje Leon z dotychczasowej nauki o Trójcy Świętej. Nie uczy jednak wprost, że jest to czyste przyjęcie natury ludzkiej do osoby Słowa, podkreślając raczej, po antiocheńsku, że „jedna i druga natura schodzą się w jedną osobę»(et in unam coeuntem personam)" ${ }^{18}$.

Dużym wkładem Leona była teza, że natury w Chrystusie nie są zmieszane w coś trzeciego, ale i nie są rozdzielne. Są one w pełni sobą: «"w całkowitej i pełnej naturze prawdziwego człowieka narodził się Bóg, ze wszystkimi własnościami swoimi i ze wszystkimi własnościami naszymi» (totus in suis, totus in nostris $)^{19}$, ale łączą się wzajemnie, przenikają się bytowo: «Każda z natur pełni swoje w łączności z drugą: Słowo mianowicie sprawuje, co Słowa jest własnością, ciało natomiast wykonuje to, co ciału przysługuje, [...] i tak jak Słowo nie wyzbywa się równej chwały z Ojcem, tak ciało nie traci charakteru naszej natury»" ${ }^{20}$ W r. 454 w mowie o Męce Pańskiej Leon pouczał:
„Wierzcie że w Chrystusie jest prawdziwe Bóstwo i prawdziwe czlowieczeństwo.
On jest i ciałem i Słowem zarazem. Podziela on istotność Ojca, podziela też naturę matki. Nie ma w nim zdwojenia osoby - nie ma też zlania się w jedno natur. Boskiej jego mocy nie dotyka cierpienie, choć jest śmiertelny w ludzkiej naturze. Posługuje się on jedną i drugą naturą, ale w ten sposób, żeby moc mogła nadawać chwałę słabości, jednak bez przyćmienia mocy przez słabość" 21.

Dzięki jedności osoby, logicznie rysuje się wymiana orzeczeń o Chrystusie. „Właściwości ludzkie mogą być odnoszone przez tożsamość osoby - do Bóstwa, np., że «Syn Boży cierpiał», a właściwości boskie mogą być przypisywane naturze ludzkiej Jezusa, np. że Jezus jest naturalnym Synem Bożym. Leon naucza, że «w obydwu naturach należy uznawać jedność osoby. Z tej właśnie racji Pismo św. mówi o Synu człowieczym, iż zstąpił z nieba; choć to Syn Boży przyjmował ciało z dziewicy, z której się narodził. I odwrotnie, o Synu Bożym mówi się, że był ukrzyżowany i złożony do grobu, chociaż te rzeczy przecierpiał nie w samym bóstwie, lecz w ludzkiej słabej naturze. W bóstwie natomiast Jednorodzony jest współwiekuisty i współistotny z Ojcem»"22. Wymiana orzeczeń jest obrazem tajemniczej dynamiki, jaka płynie z połączenia dwóch natur Chrystusa:

${ }^{18}$ Tamże, 3, PL 54, 763A, POK 24, s. XLI.

19 Tamże, 3, PL 54, 763B, POK 24, s. XLI.

${ }^{20}$ Tamże, 4, PL 54, 767BC, POK 24, s. XLIII; Bartnik, Ku integralnej chrystologii, s. 446-447.

21 Sermo 69, 3, CCL 138 A, 421: „Vera in Christo deitas et vera creditur humanitas. Ipse est caro qui Verbum, et sicut unius cum Patre substantiae, ita unius cum matre naturae. Non geminatus persona, non confusus essentia, potestate inpassibilis, humilitate mortalis, sed utraque sic utens, ut, et virtus glorificare posset infirmitatem, et infirmitas non valeret obscurare virtutem", thum. K. Tomczak, POK 24, 327.

${ }^{22}$ I Tomus ad Flavianum 5, PL 54, 771B, thum. Tomczak, POK 24, s. XLV; por. Bartnik, Ku integralnej chrystologii, art. cyt. s. 448. 
„Niewidzialny w swej naturze - widzialnym staje się w naszej, niepojęty - pozwala się pojąć, odwieczny - zaczyna istnieć w czasie, Pan wszechświata - przyjmuje na siebie służebną postać, osłaniając swój majestat niezmierzony, Bóg niedostępny z istoty swej cierpieniom - nie wzbrania się być człowiekiem cierpiętliwym, i nieśmiertelny - podlegać prawom śmierci”"23.

4. Formuła: consubstantialis Patri - consubstantialis matri. Pośród terminów, jakich Leon używa mówiąc o tajemnicy wcielenia Słowa, pojawia się formuła consubstantialis Patri - consubstantialis matri. Sam termin consubstantialis za czasów Leona jest już ugruntowany w tradycji Zachodu jako odpowiednik greckiego homousios. B. Studer wykazuje, że nasz autor przejął go $\mathrm{z}$ formuł chrystologicznych św. Augustyna ${ }^{24}$. Termin ten w odniesieniu do relacji Ojciec - Syn, oznacza tyle, co unum in substantia, oscylując pomiędzy aequalitas - gdy bazuje na zrodzeniu, a unitas - gdy bazuje na odwiecznym istnieniu $^{25}$. Pewnego rodzaju zaskoczeniem i nowością w tradycji łacińskiej jest jednak zastosowanie go w formule consubstantialis Patri - consubstantialis matri. Zwrot ten pojawia się kilkakrotnie w tekstach Leona w kontekście precyzowania kwestii chrystologicznych. Tak na przykład w Liście 31 skierowanym do Flawiana, przy ocenie nauczania Eutychesa podkreśla, że ten sam Syn, Wcielone Słowo, który jest consubstantialis Patri, raczył stać się consubstantialis matri ${ }^{26}$. Jak Leon rozumie to pojęcie, możemy spotkać wyjaśnienie w trzech jego mowach w kontekście wyraźnie antyariańskim: Jednorodzony Syn stał się prawdziwym człowiekiem w taki sposób, że pozostając tej samej substancji (homousios) z Ojcem, stał się jednocześnie tej samej substancji z matką, od której wzią ciało ${ }^{27}$.

Problem rysuje się $\mathrm{w}$ tym, że Leon ten sam termin bez żadnych obiekcji odnosił jednocześnie do dwóch różnych poziomów „bycia tej samej substancji”: z jednej strony do relacji Osób Ojca i Syna, boskiej natury, a z drugiej do relacji Wcielonego Słowa i matki, która pozostaje stworzeniem. Tym bardziej może to zaskakiwać, że Augustyn, do którego myśli sięgają korzenie teologii Leona, wprowadza tu bardzo jasną dystynkcję w sposobie orzekania tego samego terminu do natury boskiej i ludzkiej. W traktacie przeciwko Maksyminowi,

23 Tamże, 4, PL 54, 765-767, POK 24, s. XLIII.

${ }^{24}$ Por. Studer, Il concetto di consostanziale, dz. cyt., s. 600, 604.

25 Por., tamże, 509.

26 Por. Epistula 31,2, PL 54,792: „Nisi enim novus homo, factus in similitudinem carnis peccati, nostram susciperet vetustatem, et consubstantialis Patri consubstantialis esse dignaretur et matri, naturamque sibi nostram solus a peccato liber uniret, sub iugo diaboli generaliter teneretur humana captivitas".

27 Por. Sermo 30,6, CCL 138, 158: „Quia igitur iustificandis hominibus hoc principaliter opitulatur, quod unigenitus Dei etiam filius hominis esse dignatus est, ut homousios Patri Deus, id est unius substantiae, idem homo verus et secundum carnem matri consubstantialis existeret", przekład por. POK 24, 129-130. 
podejmującemu na nowo błędy arianizmu, Augustyn jasno zaznaczał, że na oznaczenie jedności tej samej „substancji” w odniesieniu do ludzi mówi się unum in natura, jednak w porządku jedności Ojca i Syna będzie to jedność, ale natura excellentiore ${ }^{28}$. Pozostaje jednak faktem, że ten sam termin consubstantialis Syna, odnoszony jest teraz w dwóch różnych wymiarach: raz do Ojca Boga, a drugi raz do Matki - stworzenia. Uważa się, że Leon mógł przejąć tę formułę z teologii greckiej, jeżeli już może nie od Cyryla, to najprawdopodobniej od przeciwników Eutychesa ${ }^{29}$. Być może, że drogę do takiego orzekania utorowało wcześniejsze, na Soborze Efeskim w 431 r., przyjęcie terminu theotokos wraz z communicatio idiomatum. Za tymi terminami przecież stoi idea, że Verbum rodzone odwiecznie przez Ojca, w tajemnicy wcielenia jest „zrodzone” w nowym porządku przez matkę - człowieka. Z tymi właśnie terminami logicznie łączą się consubstantialis Patri - consubstantialis matri. Ugruntowanie się tego terminu na Wschodzie z całą pewnością potwierdza formuła wiary Soboru Chalcedońskiego, przejmującego „wykład wiary Leona”, gdzie powraca ta sama idea z odpowiednikiem w wersji greckiej, poszerzona o wyjaśnienie: consubstantialis Patri secundum deitatem, idem consubstantialis nobis secundum humanitatem ${ }^{30}$.

\section{$* * *$}

Szkoła protestancka z końca XIX i pierwszych dziesięcioleci naszego wieku (chodzi o takie postaci jak A. Harnack czy E. Loofs) traktuje jednogłośnie chrystologię Leona jako rodzaj tylko podsumowania nauki Zachodu, minimalizując przy tym ze zrozumiałych względów jego wkład w ugruntowanie życia Kościoła. Chciałoby się mu przypisywać brak oryginalności i pogłębienia ducha tradycji ${ }^{31}$. Spokojne jednak spojrzenie na jego nauczanie świadczy jednak chyba o czym innym. Novum Leona tkwiło w klarownym sprecyzowaniu terminów teologicznych, co w ówczesnym Kościele najbardziej było potrzebne. Jego intuicje w oddaniu ducha wiary w Chrystusa, Odwieczne Słowo Ojca, które w tajemnicy wcielenia stało się człowiekiem, znalazły takie sformułowania, które z aplauzem przyjęto na największym liczebnie soborze starożytności, w Chalcedonie (451), w którym uczestniczyło ponad 500 ojców. Ówczesna powszechna aprobata oznaczała, że formułę Leona przyjęli i wcześniejsi zwolennicy Eutychesa, co nie może być sprawą mało znaczącą.

28 Por. Contra Maximinum arianum II 22, 1, PL 42, 792.

29 Por. Studer, Il concetto consubstantialis, dz. cyt. s. 606.

${ }^{30}$ Por. Concilium Chalcedonense. Definitio de duabus naturis, H. Denzinger (Enchiridion symbolorum, Freiburg 1967) nr 301, s. 108; przekład: Breviarium Fidei VI 8, s. 226.

${ }^{31}$ Por. W. Wojtasik, Nauka św. Leona, dz. cyt. s. 129. 


\section{IL MISTERO DELL'INCARNAZIONE NELL'INSEGNAMENTO DI LEONE MAGNO}

(Riassunto)

Lo studio ha di mira segnalare i tratti principali di cristologia di s. Leone Magno, maturata nel contesto di due tradizioni teologiche: alessandrina e quella antiochena. Muovendosi nel solco di una precisa terminologia teologica di Agostino, Leone delinea una visione di cristologia ,integrale" che parte dallo schema di tre elementi: natura divina, natura umana e l'unione in persona del Verbo, di cui conseguenza è la communicatio idiomatum. Una particolare attenzione merita l'impiego del termine consubstantialis, equivalente a homousios, che Leone adopera a differenza della tradizione precedente, cioè, quella agostiniana, in formula consubstantialis patri - consubstantialis matri.

La novità dell'insegnamento di s. Leone sta in una chiara precisazione di termini teologici, che infatti di allora fu l'esigenza più urgente. Le sue intuizioni nel rendere lo spirito di fede in Cristo Verbo, Figlio di Dio che nel mistero dell'Incarnazione divenne l'uomo, trovarono una tale formulazione che venne accolta all'unanimità dal concilio più numeroso d'antichità cristiana, come quello di Calcedone. 